\title{
Correction to: Developing fast enzyme recycling strategy through elucidating enzyme adsorption kinetics on alkali and acid pretreated corn stover
}

\author{
Ye Yuan ${ }^{\dagger}$, Rui Zhai ${ }^{\dagger}$, Ying Li, Xiangxue Chen and Mingjie Jin ${ }^{*}$
}

\section{Correction to: Biotechnol Biofuels (2018) 11:316 https://doi.org/10.1186/s13068-018-1315-5 \\ Following publication of the original article [1], the authors wish to update the information under the head- ing "Enzyme adsorption comparison on lignin materials derived from acid and alkali pre-treated corn stover". The corrected text is as follows:}

Enzyme adsorption comparison on lignin materials derived from acid and alkali pre-treated corn stover.

To further understand the role of lignin materials in enzyme adsorption, we enzymatically hydrolyzed dilute acid pre-treated and dilute alkali pre-treated corn stover excessively to remove all the carbohydrates that are hydrolyzable by the enzyme cocktail applied. The obtained cellulolytic enzyme lignin (CEL) materials were used to investigate their enzyme adsorption kinetics (Fig. 3), and the Langmuir adsorption model was used to fit the data (Table 2). It was found that CEL isolated from dilute alkali pre-treated corn stover (CEL-alkali-CS) had a maximum enzyme adsorption capacity (Ebm) of 10.09 $\mathrm{mg}$ protein/g CEL, and the CEL from dilute acid pretreated corn stover (CEL-acid-CS) had a much higher Ebm of $19.90 \mathrm{mg}$ protein/g CEL. The association constant for CEL-alkali-CS and CEL-acid-CS was $4.2 \mathrm{~mL} /$ $\mathrm{mg}$ and $3.5 \mathrm{~mL} / \mathrm{mg}$, respectively. The distribution coefficient $(\mathrm{Kp})$ was also calculated to characterize the interaction between enzyme and CEL. Kp of CEL-acid-CS was $69.64 \mathrm{~mL} / \mathrm{g}$, which was higher than 42.38 for CELalkali-CS, indicating that lignin isolated from dilute acid pre-treated corn stover had a higher enzyme adsorption capability than CEL-alkali-CS. Therefore, the enzyme adsorption difference in enzymatic hydrolysis of acid pretreated CS and alkali pre-treated CS (Fig. 2) is also due to the adsorption property difference of lignin.

Further to this, the authors reported an error in Fig. 3 and Table 2.

The corrected Fig. 3 and Table 2 are provided here.

\footnotetext{
*Correspondence: jinmingjie@njust.edu.cn

†Ye Yuan and Rui Zhai contributed equally to this work

School of Environmental and Biological Engineering, Nanjing University

of Science and Technology, 200 Xiaolingwei Street, Nanjing 210094, China
} 


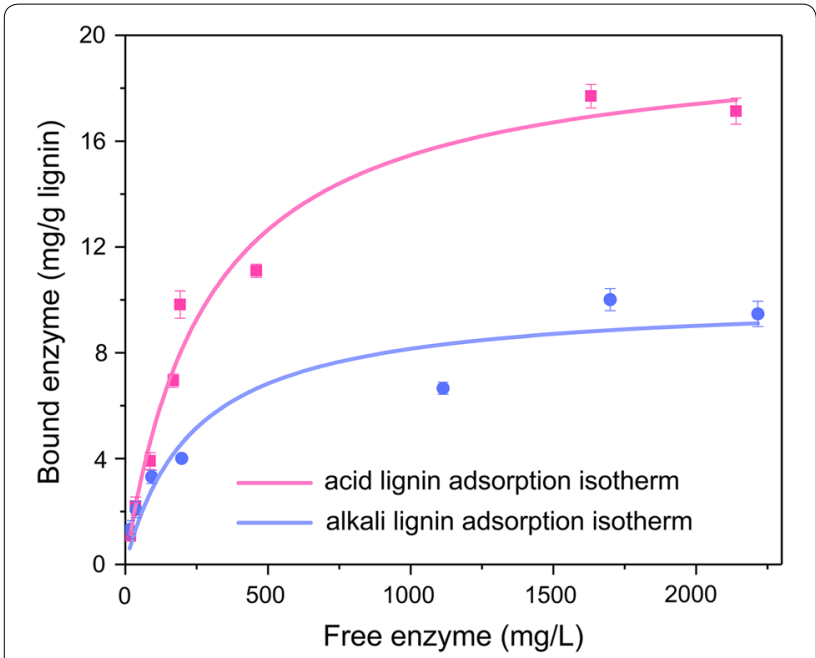

Fig. 3 Adsorption isotherms of cellulase on cellulolytic enzyme lignin materials derived from acid and alkali pre-treated corn stover. The adsorption experiments were performed by mixing CEL (solid loading at 1\%), enzyme (cellulase loading at $25-2000 \mu \mathrm{g} / \mathrm{mL}$ ) and $50 \mathrm{mM}$ sodium citrate buffer ( $\mathrm{pH} 4.8$ ) at a total volume of $2 \mathrm{~mL}$, followed by incubation at $4{ }^{\circ} \mathrm{C}$ for 60 min to reach equilibrium. Error bars represent standard errors
The original article can be found online at https://doi.org/10.1186/s1306 8-018-1315-5

\section{Publisher's Note}

Springer Nature remains neutral with regard to jurisdictional claims in published maps and institutional affiliations.

Published online: 10 December 2018

\section{Reference}

1. Yuan $Y$, Zhai R, Li Y, Chen X, Jin M. Developing fast enzyme recycling strategy through elucidating enzyme adsorption kinetics on alkali and acid pretreated corn stover. Biotechnol Biofuels. 2018;11:316. https://doi. org/10.1186/s13068-018-1315-5.

Table 2 Langmuir adsorption isotherm parameters for cellulase adsorbing onto cellulolytic enzyme lignin (CEL) materials

\begin{tabular}{lllll}
\hline Lignin & $\boldsymbol{E}_{\mathbf{b m}}(\mathbf{m g} / \mathbf{g})$ & $\boldsymbol{K}_{\mathbf{a}}(\mathbf{m L} / \mathbf{m g})$ & $\boldsymbol{K}_{\mathbf{p}}(\mathbf{m L} / \mathbf{g})$ & Adj. $\boldsymbol{R}$-square \\
\hline CEL (alkali-CS) $^{\mathrm{a}}$ & 10.09 & 4.2 & 42.38 & 0.975 \\
CEL (acid-CS) $^{\mathrm{b}}$ & 19.90 & 3.5 & 69.64 & 0.905 \\
\hline
\end{tabular}

a CEL (alkali-CS): cellulolytic enzyme lignin derived from alkali pre-treated corn stover containing $7.5 \%$ glucan, $2.3 \%$ xylan and $75.3 \%$ lignin and ash

b CEL (acid-CS): cellulolytic enzyme lignin derived from acid pre-treated corn stover containing $2.7 \%$ glucan, $0.0 \%$ xylan and $86.6 \%$ lignin and ash 